\title{
EFEK PENGHAMBATAN RADIKAL BEBAS INFUSA DAN EKSTRAK ETANOL HERBA PEGAGAN (Centella Asiatica (L.) Urb) DENGAN METODE DPPH
}

\section{FREE RADICAL SCAVENING EFFECT OF INFUSION AND ETHANOL EXTRACT PEGAGAN HERB (Centella asiatica L. Urb) USING DPPH METHOD}

\author{
Melisa Widyani ${ }^{1}$, Maria Ulfa ${ }^{2}$, Dyke Gita Wirasisya ${ }^{1}$ * \\ ${ }^{1}$ Program Studi Farmasi, Fakultas Kedokteran, Universitas Mataram, Mataram, Indonesia \\ ${ }^{2}$ Program Studi Kimia, Fakultas Matematika dan Ilmu Pengetahuan Alam, Universitas Mataram, Indonesia \\ *Email: gita@unram.ac.id
}

Diterima: 22 Januari 2019. Disetujui: 02 Maret 2019. Dipublikasikan: 31 Maret 2019

\begin{abstract}
Abstrak: Penyakit degeneratif salah satunya disebabkan oleh radikal bebas. Oleh karena itu dibutuhkan senyawa antioksidan yang berfungsi melawan kerusakan oksidatif akibat radikal bebas. Pegagan (Centella asiatica (L.) Urb) merupakan salah satu tanaman yang biasa digunakan dalam pengobatan tradisional dan mengandung senyawa aktif seperti alkaloid, flavonoid, terpenoid, tannin, steroid, kumarin, kuinon dan saponin. Penarikan senyawa aktif dari herba pegagan dilakukan dengan metode infundasi menggunakan pelarut air dan metode maserasi menggunakan pelarut etanol $70 \%$. Masing-masing ekstrak diidentifikasi kandungan senyawa kimianya dengan metode KLT dan uji tabung. Aktivitas antioksidan dari masing-masing ekstrak diuji dengan metode peredaman radikal bebas DPPH (1,1-diphenyl-2-picrilhydrazyl). Kandungan fenolik total masingimasing ekstrak ditentukan dengan metode Follin-Ciocalteu dan dinyatakan sebagai ekuivalensi asam galat (EAG). Hasil penelitian menunjukkan bahwa ekstrak etanol dan infusa herba pegagan mengandung senyawa flavonoid, terpenoid dan tannin. Ekstrak etanol dan infusa herba pegagan memiliki aktivitas terhadap DPPH dengan nilai IC50 berturut-turut sebesar 20,43 dan 64,61 $\mu \mathrm{g} / \mathrm{mL}$. Hasil ini sebanding dengan kandungan fenolik total yang terdapat dalam ekstrak etanol dan infusa herba pegagan yaitu dengan nilai berturut-turut sebesar $1,73 \pm 0,38$ dan $0,93 \pm 0,04 \mathrm{mg} \mathrm{EAG} / \mathrm{g}$ ekstrak.
\end{abstract}

Kata kunci : pegagan, infundasi, maserasi, DPPH, IC50, kandungan fenolik total

Abstract: Free radical caused degenerative disease. Therefore it takes antioxidantt compounds that function against oxidative damage due to free radicals. Pegagan (Centella asiatica (L.) Urb) are plants commonly used in traditional medication, this plant containing active compounds such as alkaloid, flavonoid, terpenoid, tanin, steroid, cumarin, quinone, and saponin. Pegagan herb was extracted using two methods, infusing and macerate using 70\% ethanol. Chemical compounds of each extract was identified by using test tube and TLC method. While antioxidant activities of each extract was examined by free radical attentuation DPPH (1,1-diphenyl-2picrilhydrazyl). Total phenolic compound was determined by Follin-Ciocalteu method and was considered as equivalent with gallic acid (GAE). This study reveals that infussion and ethanol extract pegagan herb ccontained flavonoid, terpenoid and tanin. Infussion and ethanol extract pegagan herb indicated antioxidant activities towards DPPH with IC50 as respectively; 20.43 dan $64.61 \mu \mathrm{g} / \mathrm{mL}$. This result equivalent to total phenolic compound presented in infusion and ethanol extract pegagan herb as respectively; $1.73 \pm 0.38$ and $0.93 \pm 0.04$ $\mathrm{mg} \mathrm{GAE} / \mathrm{g}$ extract.

Keywords : pegagan, infusion, maceration, DPPH, IC50, total phenolic compound

\section{PENDAHULUAN}

Penyakit degeneratif hingga saat ini telah menjadi permasalahan tersendiri bagi setiap negara diseluruh dunia serta merupakan penyebab kematian terbesar [1, 13].Penyakit degeneratif salah satunya disebabkan oleh terbentuknya radikal bebas yang bersifat reaktif terhadap sel dan jaringan tubuh. Oleh karena itu diperlukan suatu senyawa yang dapat menghambat terbentuknya radikal bebas berlebih di dalam tubuh yaitu antioksidan[12,16].

Antioksidan secara alami dihasilkan dari dalam tubuh dalam bentuk enzim, namun prosesnya tidak seratus persen efektif dan semakin berkurang seiring dengan bertambahnya usia sedangkan radikal bebas terbentuk setiap saat. Oleh karena itu, tubuh memerlukan antioksidan eksogen untuk menetralisir jumlah radikal bebas didalam tubuh $[22,25,28]$.

Antioksidan eksogen dapat dihasilkan dari sintesis bahan kimia dan dari bahan alam. Salah satu bahan alam yang berpotensi sebagai antioksidan yaitu pegagan (Centella asiatica (L.) Urb). Hashim dkk. (2011) melaporkan bahwa aktivitas antioksidan pegagan sebesar $84 \%$ 
sebanding dengan vitamin C (88\%) dan biji anggur $(83 \%)$. Pegagan merupakan tanaman liar yang banyak tumbuh di daerah perkebunan, ladang, tepi jalan dan pematang sawah [4]. Pegagan memiliki kandungan senyawa seperti gula reduksi, flavonoid, tanin, terpenoid, steroid, alkaloid, dan saponin[29]. Pegagan juga kaya akan vitamin $\mathrm{A}$, vitamin $\mathrm{B}$, vitamin $\mathrm{B} 2$, niasin, dan karoten $[5,15]$. Adapun kandungan senyawa pegagan yang berpotensi sebagai antioksidan yaitu flavonoid, terpenoid dan tanin $[2,17,19]$.

Pegagan telah lama dimanfaatkan oleh masyarakat sebagai obat tradisional baik dalam bentuk bahan segar, kering maupun yang sudah dalam bentuk ramuan[6]. Penggunaan herba pegagan secara tradisional biasanya dilakukan dengan cara merebus herba pegagan kemudian air rebusannya diminum. Senyawa yang berkhasiat sebagai antioksidan sebagian besar larut dalam air. Infusa herba pegagan memiliki aktivitas antioksidan yang lebih tinggi dibandingkan dengan ekstrak etanol dan metanol herba pegagan.

Aktivitas antioksidan dapat ditentukan menggunakan beberapa metode seperti penghambatan radikal DPPH, xantin oksidase, tiosianat, deoksiribosa dan lain-lain. Sebagian besar peneliti yaitu sebanyak 82,24\% menggunakan metode penghambatan radikal DPPH jika dibandingkan dengan metode xantin oksidase $(9,26 \%)$, tiosianat $(6,83 \%)$ dan deoksiribosa (1,67 \%) untuk mengevaluasi aktivitas antioksidan pada ekstrak tanaman.

Berdasarkan penelitian-penelitian tersebut di atas, penarikan senyawa metabolit sekunder serta aktivitas biologis dari suatu tanaman sangat dipengaruhi oleh metode ekstraksi yang digunakan. Hal inilah yang menjadi dasar peneliti untuk membandingkan pengaruh metode esktraksi terhadap aktivitas penghambatan radikal bebas herba pegagan menggunakan metode DPPH dengan Spektrofotometri UV-Vis.

\section{METODOLOGI}

Alat

Blender, peralatan maserasi, peralatan infundasi, rotary evaporator, spektrofotometer $\mathrm{UV}-\mathrm{V}$ is (Perkin Elmer), freeze drying, timbangan analitik, alat-alat gelas, botol vial, lampu UV 254 $\mathrm{nm}$, lampu UV $366 \mathrm{~nm}$, pipet tetes, pipet volume, mikropipet, pipa kapiler, plat tetes, oven, kain mori, tanur, eksikator, cawan porselen, kompor listrik, termometer, pensil, penggaris.

Bahan

Herba pegagan (Centella asiatica L. Urb), plat KLT silika gel F254 (Merck), vitamin C (ascorbic acid), DPPH (1,1-diphenyl,2pycrilhydrazyl) (Sigma Aldrich), asam galat (Sigma Aldrich), aquades, etanol 70\%, etanol p.a, metanol p.a, kloroform p.a, butanol p.a, asam asetat glasial p.a, $\mathrm{FeCl} 3$ 5\%, $\mathrm{AlCl} 3$ 10\%, Na2CO3 7,5\%, n-heksan p.a, H2SO4 10\%, etil asetat p.a, pereaksi Follin-Calcioteu, kertas saring.

\section{Identifikasi Tanaman}

Determinasi tanaman pegagan (Centella asiatica (L.) Urb) dilakukan di Laboratorium Program Studi Biologi Fakultas Matematika dan Ilmu Pengetahuan Alam Universitas Mataram.

\section{Pengumpulan Bahan}

Bahan yang digunakan adalah herba pegagan yang diperoleh dari daerah persawahan di Desa Aikmel, Lombok Timur, Nusa Tenggara Barat. Bahan diambil pada pagi hari.

\section{Pembuatan Serbuk Simplisia}

Bahan yang telah dikumpulkan, dicuci bersih dengan air mengalir untuk menghilangkan kotoran yang menempel, tiriskan kemudian dikeringanginkan di tempat yang tidak terkena sinar matahari langsung hingga kering. Tujuannya adalah agar simplisia tidak mudah rusak dan tidak terjadi penguraian kandungan senyawa kimia dalam tanaman pegagan.

\section{Pengujian Parameter Non-spesifik Simplisia}

Pengujian parameter non-spesifik simplisia herba pegagan dilakukan dengan penetapan kadar air dan kadar abu simplisia herba pegagan dengan metode gravimetri. Penetapan kadar air dilakukan dengan pemanasan dengan oven pada suhu $105^{\circ} \mathrm{C}$ selama \pm 1 jam dengan 3 kali replikasi.Sedangkan penetapan kadar abu dilakukan dengan pemanasan dengan tanur pada suhu $600^{\circ} \mathrm{C}$ selama \pm 1 jam dengan 3 kali replikasi

\section{Pembuatan Ekstrak Etanol Herba Pegagan}

Pembuatan ekstrak dengan metode maserasi adalah sebagai berikut; kurang lebih sebanyak 100 gram serbuk simplisia dimasukkan kedalam toples kaca kemudian dituangi $750 \mathrm{~mL}$ etanol $70 \%$, ditutup dan dibiarkan selama 5 hari terlindung dari cahaya sambil sesekali diaduk. Dilakukan remaserasi sebanyak 2 kali untuk memaksimalkan penyarian. Hasil ekstraksi kemudian dipekatkan menggunakan rotary evaporator hingga diperoleh ekstrak kental.

\section{Pembuatan Infusa Herba Pegagan}

Pembuatan infusa dengan metode infundasi adalah sebagai berikut; herba pegagan segar dipanaskan pada suhu $90^{\circ} \mathrm{C}$ selama 15 menit dengan perbandingan (1:10). Infusa kemudian diserkai setelah dingin lalu dilakukan pengeringan ekstrak menggunakan freexze drying hingga diperoleh ekstrak kering. 


\section{Pengujian Karakteristik Ekstrak}

Pengujian karakteristik ekstrak etanol dan infusa herba pegagan meliputi identitas ekstrak, uji organoleptis dan perhitungan rendemen ekstrak Skrining Fitokimia Ekstrak Etanol dan Infusa Herba Pegagan

Skrining fitokimia ekstrak etanol dan infusa herba pegagan meliputi identifikasi flavonoid, terpenoid dan tannin dilakukan dengan uji tabung kemudian dilanjutkan penegasannya menggunakan KLT. Pada uji tabung digunakan pereaksi asam sulfat untuk identifikasi flavonoid; pereaksi kloroform dan asam sulfat untuk identifikasi terpenoid; besi II klorida untuk identifikasi tannin. Sedangkan pada uji KLT digunakan pereaksi $\mathrm{AlCl} 3$ $10 \%$ dengan eluen kloroform:etil asetat:butanol (5:1:4) untuk identifikasi flavonoid dan dideteksi pada sinar UV $366 \mathrm{~nm}$; pereaksi H2SO4 10\% dengan eluen kloroform:metanol (3:1) untuk identifikasi terpenoid dan dideteksi pada sinar UV $366 \mathrm{~nm}$; pereaksi $\mathrm{FeCl} 3$ 5\% dengan eluen metanol:air (6:4) untuk identifikasi tannin dan dideteksi pada sinar tampak.

\section{Penentuan Kandungan Fenolik Total}

Penentuan kandungan fenolik total pada ekstrak etanol dan infusa herba pegagan dilakukan dengan metode Follin-Ciocalteau. Kandungan fenolik total dalam ekstrak etanol dan infusa herba pegagan dinyatakan sebagai $\mathrm{mg} / 100 \mathrm{~mL}$ ekuivalen asam galat (EAG). Larutan ekstrak etanol dan infusa herba pegagan $(1000 \mu \mathrm{g} / \mathrm{mL})$ dan larutan asam galat $(10 ; 20 ; 30 ; 40$ dan $50 \mu \mathrm{g} / \mathrm{mL})$ masingmasing sebanyak $300 \mu \mathrm{L}$ dipipet kedalam tabung reaksi kemudian ditambahkan $1,5 \mathrm{~mL}$ reagen Follin-Ciocalteau (1:10) dan digojog, kemudian diinkubasi selama 3 menit lalu ditambahkan 1,2 $\mathrm{mL} \mathrm{Na} 2 \mathrm{CO} 37,5 \%$ dan digojog hingga homogen. Campuran kemudian didiamkan selama 15 menit. Serapan kemudian diukur menggunakan spektrofotometer UV-Vis pada panjang gelombang $754 \mathrm{~nm}$.

\section{Uji Pendahuluan Aktivitas Antioksidan}

Uji pendahuluan aktivitas antioksidan ekstrak etanol dan infusa herba pegagan dilakukan dengan metode Demirezer dkk., (2001) dengan sedikit modifikasi. Fase diam yang digunakan adalah silika gel F254 dengan luas 4 x $10 \mathrm{~cm}$ dengan jarak elusi $8 \mathrm{~cm}$. fase gerak yang digunakan yaitu BAW (3:1:1). Bercak yang terbentuk diamati dengan sinar tampak setelah dilakukan penyemprotan dengan larutan DPPH $0.2 \%$. Hasil positif menunjukkan terbentuknya bercak berwarna kuning pucat dengan latar belakang berwarna ungu. Pengukuran Absorbansi Peredaman Radikal Bebas menggunakan Spektrofotometri UV-Vis

Uji aktivitas antioksidan ekstrak etanol dan infusa herba pegagan dilakukan dengan metode DPPH yang digunakan Molyneux (2004) dengan sedikit modifikasi. Sebanyak $2 \mathrm{~mL}$ ekstrak etanol dan infusa herba pegagan dengan konsentrasi 10 ; 20; 40; 60; dan $80 \mu \mathrm{g} / \mathrm{mL}$ ditambahkan kedalam 2 $\mathrm{mL}$ DPPH $0,1 \mathrm{mM}$. Campuran digojog dan diinkubasi selama 30 menit ditempat gelap. Selanjutnya dilakukan pengukuran absorbansi pada $\lambda$ maks $517 \mathrm{~nm}$. Perlakuan yang sama juga dilakukan untuk larutan blanko DPPH dan kontrol positif vitamin $\mathrm{C}$ dengan konsentrasi $1 ; 2 ; 4 ; 6$; dan $8 \mu \mathrm{g} / \mathrm{mL}$. Larutan blanko terdiri dari $2 \mathrm{~mL}$ DPPH $0,1 \mathrm{mM}$ dan $1 \mathrm{~mL}$ etanol p.a. Data hasil pengukuran absorbansi dianalisa persentasi aktivitas antioksidannya menggunakan persamaan berikut:

$$
\mathrm{I}=\frac{\mathrm{A} 0-\mathrm{A} 1}{\mathrm{~A} 0} \times 100 \%
$$

Keterangan: $\mathrm{A} 0=$ Absorbansi blanko; $\mathrm{A} 1=$ Absorbani sampel; I = Persen Inhibisi

\section{HASIL DAN PEMBAHASAN Preparasi Sampel}

Pegagan (Centella asiatica (L.) Urb) diperoleh dari daerah persawahan di Desa Aikmel, Lombok Timur, Nusa Tenggara Barat. Pengambilan sampel dilakukan pada satu tempat dengan tujuan untuk menghindari variasi kandungan senyawa aktif dalam tumbuhan[24].

Parameter Non-Spesifik Simplisia

Pengujian parameter non spesifik simplisia herba pegagan yang dilakukan pada penelitian ini meliputi penetapan kadar air dan kadar abu simplisia. Adapun data kasar air dan kasar abu simplisia herba pegagan dapat dilihat pada Tabel 1. Hasil penetapan kadar air dan kadar abu yang diperoleh pada penelitian ini sudah sesuai dengan acuan dari Departemen Kesehatan RI (1995) dan Famakope Herbal (2008).

Tabel 1. Hasil Uji Kadar Air dan Kadar Abu

\begin{tabular}{cccc}
\hline No. & Data Karakteristik & Hasil Pengujian & Parameter \\
\hline 1. & Kadar Air & $6.8 \%$ & $\leq 7.6 \%$ \\
2. & Kadar Abu & $13 \%$ & $\leq 18.05 \%$ \\
\hline
\end{tabular}




\section{Ekstraksi}

Maserasi merupakan ekstraksi dengan cara dingin, tidak memerlukan pemanasan yang dapat merusak zat aktif yang tidak tahan terhadap pemanasan. Filtrat hasil maserasi dikumpulkan kemudian dipekatkan menggunakan rotary evaporator dengan suhu tidak lebih dari $60^{\circ} \mathrm{C}$ hingga diperoleh ekstrak kental. Prinsip rotary evaporator terletak pada penurunan tekanan sehingga dapat menguapkan pelarut dibawah titik didihnya. Penggunaan rotary evaporator akan mempermudah pengontrolan suhu dan meminimalkan resiko terjadinya oksidasi oleh udara yang mungkin terjadi selama proses penguapan yang akan merusak senyawa-senyawa antioksidan. Selain manfaat tersebut, dilihat dari segi ekonomi, cairan penyari hasil penguapan dapat digunakan kembali [24].

Infundasi merupakan metode ekstraksi menggunakan pemanasan dengan pelarut air dengan tujuan untuk mendapatkan zat aktif yang berrsifat polar dapat tersari dengan optimal. Zat aktif yang dimaksud seperti polifenol dan flavonoid yang bersifat sebagai antioksidan dimana flavonoid terdapat dalam tanaman kebanyakan dalam bentuk glikosida flavonoid yang bersifat polar sehingga penyariannya dapat dilakukan dengan air panas. Pemekatan ekstrak dilakukan menggunakan Freeze drying hingga diperoleh ekstrak kering. Prinsip penggunaan freeze drying adalah proses menghilangkan kandungan air dalam suatu sampel yang telah beku tanpa melalui fase cair terlebih dahulu.

Pengujian Parameter Spesifik Ekstrak

Identitas ekstrak yang diperoleh memiliki nama yaitu ekstrak etanol herba pegagan dan infusa herba pegagan yang diambil dari tanaman Centella asiatica (L.) Urb atau dengan nama Indonesia pegagan.

Hasil organoleptis ekstrak etanol herba pegagan dan infusa herba pegagan telah sesuai dengan Farmakope Herbal (2009) yang menyatakan identitas ekstrak herba pegagan berkonsistensi kental, berwarna hijau kecoklatan dan berbau khas dan memiliki rasa khelat.

Ekstrak etanol herba pegagan yang dihasilkan berwarna hijau kecoklatan sedangkan infusa herba pegagan berwarna hijau tua. Rendemen ekstrak diperoleh berdasarkan perbandingan ekstrak kental dengan berat awal dikalikan 100\%. Hasil rendemen ekstrak etanol herba pegagan sebesar $12.61 \%$ sedangkan rendemen infusa herba pegagan sebesar $2.97 \%$. Rendemen ini menunjukkan banyaknya senyawa bioaktif yang larut dalam pelarut.

\section{Hasil Uji Fitokimia Herba Pegagan dengan KLT dan Uji Tabung}

Hasil penapisan fitokimia pada ekstrak etanol herba pegagan dengan KLT menunjukkan bahwa ekstrak etanol dan infusa herba pegagan mengandung flavonoid, terpenoid dan tannin sedangkan pada infusa herba pegagan tidak terdeteksi ketiga senyawa tersebut (Tabel 2). Namun pada penapisan fitokimia menggunakan uji tabung menunjukkan bahwa ekstrak etanol dan infusa herba pegagan mengandung flavonoid, terpenoid dan tannin dengan intensitas yang lebih tinggi pada ekstrak etanol herba pegagan.

Tabel 2. Hasil Uji Fitokimia Ekstrak Etanol dan Infusa Herba Pegagan (Uji Tabung)

\begin{tabular}{ccccc}
\hline No. & Golongan senyawa & Pereaksi & Ekstrak etanol & Infusa \\
\hline 1. & Flavonoid & $\mathrm{H}_{2} \mathrm{SO}_{4}$ & ++ & + \\
2. & Terpenoid & $\mathrm{CHCl}_{3}+\mathrm{H}_{2} \mathrm{SO}_{4}$ & ++ & + \\
3. & Tanin & $\mathrm{FeCl}_{3} 10 \%$ & ++ & + \\
\hline
\end{tabular}

Tabel 3. Hasil Uji Fitokimia Ekstrak Etanol dan Infusa Herba Pegagan (KLT)

\begin{tabular}{cccccc}
\hline No. & Golongan senyawa & Eluen & Pereaksi & Ekstrak etanol & Infusa \\
\hline 1. & Flavonoid & BAW $(4: 1: 5)$ & AlCl3 10\% & + & - \\
2. & Terpenoid & Kloroform:Metanol (3:1) & H2SO4 10\% & + & - \\
3. & Tanin & Metanol:Air (6:4) & FeCl3 5\% & + & - \\
\hline
\end{tabular}

senyawa yang mengandung gugus fenolik. Pereaksi

\section{Hasil Penetapan Kandungan Fenolik Total}

Hasil penetapan kandungan fenolik total ekstrak etanol dan infusa herba pegagan secara kualitatif dengan pereaksi Follin-Ciocalteau menunjukkan bahwa ekstrak etanol dan infusa herba pegagan memiliki kandungan fenolik total yang ditandai dengan terjadinya perubahan warna menjadi biru (Gambar 1). Warna biru yang terbentuk disebabkan karena adanya reaksi reduksi oleh pereaksi Follin-Ciocalteau dan reaksi oksidasi oleh
Follin-Ciocalteau akan mengalami proses reduksi dari fosfomolibdat tungsten menjadi heteropolimolibdenum biru[26]. Hal ini sesuai dengan penelitian Ahda dkk., (2014) yang melakukan penentuan kandungan fenolik total pada ekstrak etanol pegagan dan ekstrak etanol majapahit dengan pereaksi Follin-Ciocalteau.

Pada Gambar 1 diatas menunjukkan adanya perbedaan hasil uji kualitaif pada ekstrak etanol dan infusa herba pegagan. Ekstrak etanol herba pegagan 
menghasilkan warna biru yang lebih pekat dibandingkan dengan infusa herba pegagan setelah direkaiskan dengan pereaksi Follin-Ciocalteau. Pereaksi Follin-Ciocalteau sensitif terhadap reaksi reduksi oleh senyawa polifenol sehingga menyebabkan terbentuknya warna biru. Hasil de Oliveira dkk., (2012) menyebutkan bahwa untuk mendapatkan estimasi kasar jumlah kandungan fenolik total dalam ekstrak dapat dilakukan menggunakan pereaksi Follin-Ciocalteau.

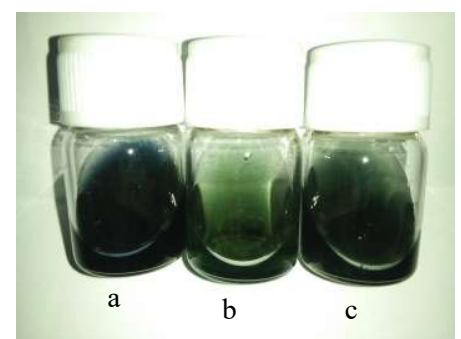

Gambar 1. Hasil Reaksi Fenolik Total dengan Pereaksi Follin-Ciocalteau; a) Asam Galat, b) Infusa Herba Pegagan, c) Ekstrak Etanol Herba Pegagan.

Hasil ini diperkuat dengan dilakukannya penentuan kandungan fenolik total yang menunjukkan kandungan senyawa fenol pada ekstrak etanol dan infusa herba pegagan secara berturut-turut yaitu $1.73 \pm 0.38$ dan $0.93 \pm 0.04 \mathrm{mg}$ (EAG) / g ekstrak (Tabel 4). Senyawa fenolik terutama polifenol bersifat antioksidan karena dapat mengadakan reaksi reduksi-oksidasi yang memungkinkan menjadi agen pereduksi, donor hidrogen, peredam oksigen singlet dan pengkhelat logam[21].

Tabel 4. Kandungan Fenolik Total Ekstrak Etanol dan Infusa Herba Pegagan

\begin{tabular}{lc}
\hline $\begin{array}{c}\text { Ekstrak Herba } \\
\text { Pegagan }\end{array}$ & $\begin{array}{c}\text { Kandungan Fenolik Total } \\
(\mathrm{mg}(\mathrm{EAG}) / \mathrm{g} \text { ekstrak })\end{array}$ \\
\hline Ekstrak Etanol & $1,73 \pm 0,38$ \\
Infusa & $0,93 \pm 0,04$ \\
\hline
\end{tabular}

\section{Hasil Uji Pendahuluan Aktivitas Antioksidan Secara KLT}

Uji pendahuluan ini bertujuan untuk mengetahui ada tidaknya senyawa aktif didalam ekstrak yang memiliki aktivitas antioksidan dalam meredam radikal bebas DPPH. Ekstrak etanol dan infusa herba pegagan yang telah ditotolkan pada plat KLT silika gel F254 menggunakan mikropipet, dielusi menggunakan fase gerak BAW (3:1:1).

Pada masing-masing ekstrak menghasilkan 1 spot yang berbeda. Pengamatan hasil kromatografi dapat dilakukan secara visual, fisika dan kimia. Bercak pada pemisahan KLT umumnya merupakan bercak yang tidak berwarna sehingga untuk penentuannya dapat dilakukan secara kimia maupun fisika[11]. Pengamatan secara fisika dilakukan dengan mengamati plat KLT dibawah sinar UV 366 $\mathrm{nm}$ yang akan menghasilkan bercak noda yang berpendar dengan latar belakang berwarna gelap sehingga spot dapat terlihat secara visual.

Pada pengamatan dibawah sinar UV $366 \mathrm{~nm}$ tidak terlihat bercak, hal ini dapat terjadi karena kemungkinan senyawa yang berpotensi sebagai antioksidan memiliki panjang gelombang dibawah rentang 200-400 $\mathrm{nm}$.

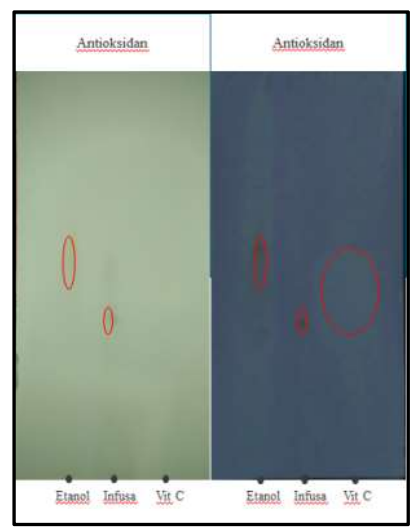

(a)

(b)

Gambar 2. Hasil KLT Uji Antioksidan

Pengamatan secara kimia dilakukan dengan menggunakan pereaksi DPPH $0,1 \mathrm{mM}$ untuk mendeteksi bercak pada uji pendahuluan aktivitas antioksidan. Senyawa yang diduga memiliki aktivitas antioksidan pada hasil pemisahan kromatografi diatas yaitu $\mathrm{Rf} 0,56$ pada ekstrak etanol herba pegagan; Rf 0,37 pada infusa herba pegagan dan $\mathrm{Rf} 0,50$ pada vitamin $\mathrm{C}$ tersebut setelah disemprot dengan larutan DPPH $0,1 \mathrm{mM}$ menunjukkan hasil positif yang ditandai dengan terbentuknya warna kuning pucat dengan latar belakang ungu. Terbentuknya bercak kuning setelah penyemprotan pereaksi DPPH disebabkan karena terdapat senyawa yang dapat mendonorkan atom hidrogen didalam ekstrak etanol dan infusa herba pegagan sehingga dapat mengakibatkan molekul DPPH tereduksi yang diikuti dengan perubahan warna ungu dari larutan DPPH menjadi kuning bening [20].

Hasil Uji Aktivitas Antioksidan dengan Metode DPPH menggunakan Spektrofotometri UV-Vis

Penentuan aktivitas antioksidan secara kuantitatif menggunakan metode DPPH. Metode DPPH diilih karena metode ini merupakan metode yang paling sederhana, mudah, cepat dan sensitif serta hanya memerlukan sampel yang sedikit sehingga dapat digunakan secara luas untuk menguji kemampuan senyawa yang berperan sebagai pendonor electron[18]. 
Hasil uji aktivitas antioksidan ekstrak etanol dan infusa herba pegagan memperlihatkan bahwa ekstrak etanol herba pegagan mempunyai aktivitas antioksidan yang lebih tinggi dibandingkan dengan infusa herba pegagan dengan IC50 $20.43 \mu \mathrm{g} / \mathrm{mL}$ (Tabel 5). Kemampuan peredaman radikal bebas berkorelasi dengan kandungan fenol dari suatu ekstrak. Walaupun begitu ekstrak etanol dan infusa herba pegagan yang diuji dapat diakatakan aktif sebagai antioksidan karena memberikan nilai IC50 kurang dari $100 \mu \mathrm{g} / \mathrm{mL}$ (20.43 dan $64.61 \mu \mathrm{g} / \mathrm{mL}$ ). Namun bila dibandingkan dengan nilai IC50 pada vitamin $\mathrm{C}(3.45 \mu \mathrm{g} / \mathrm{mL})$ aktivitasnya jauh lebih rendah.

Tabel 5. Aktivitas Antioksidan Ekstrak Etanol dan Infusa Herba Pegagan terhadap Radikal DPPH

\begin{tabular}{cccc}
\hline Sampel & Konsentrasi $(\mu \mathrm{g} / \mathrm{mL})$ & Inhibisi $(\%)$ & IC50 $(\mu \mathrm{g} / \mathrm{mL})$ \\
\hline \multirow{3}{*}{ Ekstrak Etanol } & 10 & 44,87 & \\
& 20 & 49,15 & 20,43 \\
& 40 & 61,57 & \\
& 60 & 74,94 & \\
Infusa & 80 & 92,31 & \\
& 10 & 8,27 & \\
& 20 & 15,41 & \\
& 40 & 33,27 & \\
& 60 & 47,80 & 3,45 \\
Vitamin C & 80 & 60,12 & \\
& & 28,16 & \\
& & 36,18 & \\
& 2 & 55,01 & \\
& 4 & 75,02 & \\
& 6 & 88,84 & \\
\hline
\end{tabular}

\section{KESIMPULAN DAN SARAN}

Rendemen ekstrak etanol dan infusa herba pegagan yaitu $12,61 \%$ dan $2,96 \%$. Kandungan senyawa kimia dalam ekstrak etanol dan infusa herba pegagan yaitu flavonoid, terpenoid dan tannin. Ekstrak etanol dan infusa herba pegagan mempunyai aktivitas peredaman radikal bebas DPPH dengan nilai IC50 20,43 $\mu \mathrm{g} / \mathrm{mL}$ dan 64,61 $\mu \mathrm{g} / \mathrm{mL}$. Kandungan fenolik total ekstrak etanol dan infusa herba pegagan yaitu sebesar $1.73 \pm 0.38$ dan $0.93 \pm 0.04 \mathrm{mg}(\mathrm{EAG}) / \mathrm{g}$ ekstrak.

\section{DAFTAR PUSTAKA}

[1] Ahda, M., Fiqrirozi., Gina, N.H., Ulfah, L., Tomy, H., Yuni, A. 2014. Optimation of Ethanole Extract of Centella asiatica and Cresentia cujete Composition as Natural Antioxidant Source. Eksanta., Vol. 14, No. 2, p 9-16.

[2] Amarowicz, R., 2007. Tannins: The new natural antioxidant? Eur.J.Lipid.Sci.Tchnol.,Vol. 1 No. 109, p 549-551.

[3] Badarinath, A.V., Mallikarjuna, K., Chetty, C.M.S., Ramkanth, S., Rajan, T.V.S., Gnanaprakash, K., 2010. A revies on in-vitro antioxidant methods: comparisons, correlation dan consideration, Int.J.Pharm.Tech.Res., Vol. 2, No. 2, p 1276-1285.
[4] Besung, K.I., 2009. Pegagan (Centella asiatica) sebagai alternative pencegahan infeksi pada ternak, Jurnal Penelitian Universitas Udayana., Vol. 2, No. 1.

[5] Bhavana, D., Jyoti, K.C. 2011. Centella asiatica The Elixir of Life, International Journal of Research in Ayurveda and Pharmacy, Vol. 2, No. 2, p 431-438.

[6] Coskun, O., Kanter, M., Korkmaz, A., Oter, S., 2005. Quercetin a flavonoid antioxidant, prevent and protects streptozotocin induced oxidative stress and beta cell damage in rat pancreas, Pharmachol.Res., Vol. 51, No. 2, p 177-123.

[7] de Oliveira, A.M.F., Pinheiro, L.S., Pereirea, C.K.S., Matias, W.N., Gomes, R.A., Chaves, O.S., de Souza, M.F.V., de Almeida, R.N., de Assis, T.S. 2012. Total Phenolic Content and Antioxidant Activity of Cabalash (Crescentia cujete). Afr.J.Biotechnol., Vol. 10, No. 84, p 19631-19636.

[8] Demirezer, L.O., Kruuzum-Uz, A., Bergere, I. Schiewe, H.J.., Zeeck, A. 2001. The Structure of Antioxidant and Cytotoxic Agents from Natural Source Antraquinones and Tanni from Roots of Rumexpatientia. Phytochemistry., Vol. 58, No. 1, p 12131217.

[9] Departemen Kesehatan Republik Indonesia. 1995. Farmakope Indonesia Edisi IV. 
Jakarta: Departemen Kesehatan Republik Indonesia.

[10] Departemen Kesehatan Republik Indonesia. 2008. Farmakope Herbal Indonesia Edisi I. Jakarta: Departemen Kesehatan Republik Indonesia.

[11] Gandjar, I.G., Rohman, A. 2009. Kimia Farmasi Analisis. Yogyakarta: Pustaka Pelajar. p 353-376, 456-480.

[12] Giriwijoyo, Santosa. 2004. Ilmu Faal Olahraga Fungsi Tubuh Manusia pada Olahraga. Bandung: FPOK-UPI.

[13] Handayani, A., Roosihermiatie, B., Maryani, H., 2007. Faktor-faktor yang berhubungan dengan pola kematian pada penyakit degeneratif di Indonesia, Buletin Penelitian Sistem Kesehatan, Vol. 13, No. 1, p 42-53.

[14] Hashim, P., Sidek, H., Helan, M.H.M., Sabery, A., Palanisamy, U.D., Ilham, M., 2011. Triterpene composition and bioactivities of Centella asiatica, Molecules., Vol. 16, No. 2, p 1310-1322.

[15] Jamil, S.S., Nizami, Q., Salam, M. 2007. Centella asiatica (L.) Urban: A Review, Natural Product Radiance, Vol. 6, No. 2, p 158-170.

[16] Karyadi, E., 1997. Antioksidan: resep awet muda dan umur panjang dari uji aktivitas antiradical dengan metode DPPH dan penetapan kadar fenol total ekstrak daun keladi tikus (Thyponium divaricatum (Linn) Dence), Pharmacon., Vol. 6, No.2, p 51-56.

[17] Meena, H., Pandey, H.K., Arya, M.C., Ahmed, Z., 2012. Evaluation of antioxidant activity of two important memory enhancing medicinal plants Baccopa monnieri and C.asiatica, Indian.J.Pharmacol., Vol. 1. No. 44, p 114-117.

[18] Molyneux, P. 2004. The Use of the Stable Free Radikal DPPH (1-1 diphenyl, 2picrylhydrazyl) for Estimating Antioxidant Activity. J.S.T., Vol. 26 No. 2, p 211-219.

[19] Nurlaily, A., Noor, B.A.R., Musalmah, M., 2012. Comparative antioxidant and antiinflammatory activity of different extract of
Centella asiatica (L.) Urban and its active compound, asiaticoside and madecasoside, Medicine and Health., Vol. 1, No. 7, p 6272.

[20] Prakash, A., Rigelhof, F., Miller, E. 2011. Antioxidant Activity. Meddaliaoan Laboratories., Vol. 19, No. 2, p 1-4.

[21] Rahman, M.S., Hossain, A., Rahaman, N., Fatima, T., Nahar, B., Uddinm M.A., Basunia. 2013. Antioxidant Activity of Centella asiatica (Linn.) Urban: Impact of Extraction Solvent Polarity. J.Pharmacog.Phytochem., Vol. 1, No. 6, p 27-32.

[22] Rohdiana, D., 2001. Aktivitas daya tangkap radikal polifenol dalam daun teh, Majalah Jurnal Indonesia., Vol. 1, No. 1, p 53-58.

[23] Sa'adah, Hayatus., Henny, Nurhasmawati., dan Vivi, Permatasari., 2017. Pengaruh metode ekstraksi terhadap kadar flavonoid ekstrak etanol umbi bawang dayak (Eleutherine palmifolia (L.) Merr) dengan metode spektrofotometri. J.P.S.T., Vol. 1, No. 1, p 1-9.

[24] Salamah, N., Nurushoimah. 2014. Uji Aktivitas Antioksidan Ekstrak Etanol Herba Pegagan (Centella asiatica (L.)) dengan Metode Penghambatan Degradasi BetaKaroten . Yogyakarta: Universitas Ahmad Dahlan. p 177-181.

[25] Sen, S., Chakraborty, R., Sridhar, C., Reddy, Y.S.R., dan Biplab, D., 2010. Free radicals, antioxidants, disease and phtomedicines: current status and future prospect. Int.J.Pharm.Sci.Rev.Res., Vol. 3, No.1, p 91100.

[26] Walker, J.M. 2002. The Protein Protocols Hanbook. New York: Humana Press. p 1-6.

[27] WHO. 2011. Top Causes of Death.

[28] Winarsih, H., 2007. Antioksidan Alami dan Radikal Bebas. Yogyakarta: IKPI.

[29] Zheng, C.J., Qin, L.P., 2007. Chemical components of Centella asiatica and their bioactives. Journal of Chinese Integrative Medicine., Vol. 1 No. 5, p 348-351. 